\title{
Process Optimization on Chitinase Production by Locally Isolated Enterobacter sp. and Zymomonas sp.
}

\author{
Lisa G. A. Ong, Hoi Khei Lam, Mei Yin Lim, and Tian Xiang Tan
}

\begin{abstract}
Twenty three isolates which were collected from soil samples around UTAR, Kampar, Perak and Pantai Bagan Nakhoda Omar, Sabak, Selangor were successfully isolated using chitinase selective medium supplemented with colloidal chitin and bromocresol purple as indicator. Based on their enzyme production, two most potent isolates were selected for identification. The isolates were tentatively identified as Enterobacter sp. and Zymomonas sp. based on their morphological and biochemical test. The preliminary study showed that both Enterobacter sp. and Zymomonas sp. produced the highest chitinase at $\mathbf{4 8}$ hours. The process optimization was carried out using one-factor-at-a-time and the parameters involved were the percentage of colloidal chitin, incubation temperature and $\mathrm{pH}$. The optimum parameters for Enterobacter sp. to produce chitinase were $5 \%$ colloidal chitin, at $30{ }^{\circ} \mathrm{C}$ and $\mathrm{pH} 7$ with $2.92 \mathrm{U} / \mathrm{mL} /$ day of productivity. As for Zymomonas sp., the chitinase productivity $(2.54 \mathrm{U} / \mathrm{mL} / \mathrm{day})$ was obtained from the optimum conditions i.e. $15 \%$ colloidal chitin at $30^{\circ} \mathrm{C}$ and $\mathrm{pH} 6$.
\end{abstract}

Index Terms-Bromocresol purple, colloidal chitin, Enterobacter, Zymomonas.

\section{INTRODUCTION}

Chitinase is a glycosyl hydrolase enzyme which hydrolyzes chitin that can be found in bacteria, fungi, plants, insects, mammals and viruses. The chitinase produced by these organisms have various roles, i.e. chitin metabolism in growing hyphae, defense mechanisms in response to pathogens and abiotic stress, in nutrition and parasitism. Other than that, chitinase has been used as biopesticides and inhibitors such as phytopathogen inhibition to strength plant defenses [1]. Bacterial chitinase are widely distributed in the genus of Serratia [2], Bacillus [3], Vibro [4], Aeromonas [5] and etc.

The applications of chitinase include environmental remediation, alcohol fermentation, biomedicine, pest control [3]-[6] etc. Chitin is the most abundant renewable biomass after cellulose. Chitin is mainly obtained from crustaceans and insect and about $1-100$ billion metric tons of these wastes are obtained from aquatic life [7]. Most of these wastes are disposed of through land filling, incineration and/or ocean dumping. Thus an economical and commercially feasible method is needed to manage this huge amount of chitinous waste, which may cause environmental

Manuscript received February 5, 2017; revised May 5, 2017.

L. G. A. Ong is with the Department of Biological Science, Faculty of Science, Universiti Tunku Abdul Rahman, 31900 Kampar, Perak, Malaysia (e-mail: ongga@utar.edu.my).

H. K. Lam, M. Y. Lim, T. X. Tan were with the Department of Biological Science, Faculty of Science, Universiti Tunku Abdul Rahman, 31900 Kampar, Perak, Malaysia. pollution and wastage of natural resources [3]. These can be overcome by recycling the nutrients from the chitinous waste to the environment by microorganisms [8]. Due to the industrial applications of chitinase, numerous studies had been done to optimize fermentation conditions to maximize the production of chitinase from different microbial sources [3], [9], [10]. The objectives of this present work were to isolate prominent chitin degrading bacteria from soil samples and optimize the fermentation parameters to maximize its production.

\section{MATERIALS AND METHODS}

\section{A. Soil Samples Collection}

Soil samples were collected aseptically in a sterile sample collection bottle from Westlake hostel, lakeside near to UTAR block E and UTAR entrance, as well as Pantai Bagan Nakhoda Oman, Sabak Bernam, Selangor.

\section{B. Preparation of Colloidal Chitin}

The modified method of [5] was used to prepare the colloidal chitin using chitin powder from crab shells (Malacai tesque, Japan), where $5 \mathrm{~g}$ of the chitin powder was treated with $75 \mathrm{~mL}$ of concentrated $\mathrm{HCl}$ and vigorous stirred at $30^{\circ} \mathrm{C}$ for $60 \mathrm{~min}$. The mixture was then treated with $2 \mathrm{~L}$ of cold distilled water $\left(\sim 4{ }^{\circ} \mathrm{C}\right)$ and centrifugation at $12,000 \mathrm{rpm}$ for $25 \mathrm{~min}$ to obtain precipitated colloidal chitin. The colloidal chitin was washed with approximate $1 \mathrm{~L}$ of sterile distilled water and centrifuged again at 12,000 rpm for 25 min to collect the white precipitate. The precipitate was washed with distilled water until it reached $\mathrm{pH} 7$ [11]. The colloidal chitin was then pressed between filter paper to remove additional moisture and will be used as substrate.

\section{Isolation and Screening of Chitinase Producing Bacteria}

The collected soil samples $(2 \mathrm{~g})$ was added with $18 \mathrm{~mL}$ of sterile distilled water and mixed thoroughly. A 10 -fold serial dilution was carried out and the diluted sample $(0.1 \mathrm{~mL})$ was transferred onto chitin agar medium which consist of $(\mathrm{g} / \mathrm{L})$ : $\mathrm{MgSO}_{4} \cdot 7 \mathrm{H}_{2} \mathrm{O}, 0.3 ;\left(\mathrm{NH}_{4}\right)_{2} \mathrm{SO}_{4}, 3 ; \mathrm{KH}_{2} \mathrm{PO}_{4}$, 2; citric acid monohydrate, 1; agar, 15; colloidal chitin, 4.5; bromocresol purple, 0.15; Tween-80, $200 \mu \mathrm{L}$ and adjusted the $\mathrm{pH}$ to 4.7 [12]. Colonies showing purple zone after incubation of $24 \mathrm{~h}$ at $30{ }^{\circ} \mathrm{C}$ were considered as chitinase producing bacteria.

\section{Characterization of Chitin Lytic Bacterium}

The identification of Isolates SH 17 and SPBNO 1 was carried out according to the methods as describe in Bergey's Manual of Determinative Bacteriology [13]. The tests carried were: gram stain, arginine dihydrolase, lysine decarboxylase, 
citrate utilization, catalase, hydrogen sulfide, indole, triple sugar iron, starch hydrolysis, gelatin hydrolysis, oxidase, mobility, oxidation fermentation, methyl red and Voges Proskauer.

\section{E. Optimization of Chitinase Production}

The optimization was carried based on the one-factor-at-a-time where Lauria Bertaini (LB) broth (g/L: tryptone, 10; yeast extract, 5; $\mathrm{NaCl}, 10$ amended with colloidal chitin 5, pH 7) was used for the chitinase production. To determine the optimum time for chitinase production, the bacteria (10\%) was inoculated and incubated at $30{ }^{\circ} \mathrm{C}, 200$ rpm for 7 days. Sampling was carried out every 24 h, where the cultures were centrifuged at 10,000 rpm for $14 \mathrm{~min}$ and the supernatant was used for chitinase assay. Effect of different concentration of colloidal chitin $(5-20 \mathrm{~g} / \mathrm{L})$ was carried to determine the best substrate concentration. After that, with the optimized substrate concentration, different incubation temperature $\left(28-30^{\circ} \mathrm{C}\right)$ will be investigated and follow by different $\mathrm{pH}(4-7)$.

\section{F. Chitinase Assay}

Chitinase assay was performed based on the release of reducing sugar from colloidal chitin according to [14] with slight modification. Crude enzyme $(0.5 \mathrm{~mL})$ was added with equal volume of $1 \%(\mathrm{w} / \mathrm{v})$ colloidal chitin in phosphate buffer $(0.1 \mathrm{M}, \mathrm{pH} 7)$. After incubation at $37^{\circ} \mathrm{C}$ for 2 hours, the reaction mixture was added with $1 \mathrm{~mL}$ of DNS reagent and boiled for $5 \mathrm{~min}$. The reaction mixture was centrifuged at 9,000 rpm for $5 \mathrm{~min}$ and the supernatant was measured at 540 $\mathrm{nm}$. One unit (U) of chitinase was defined as the amount of enzyme which releases one $\mu \mathrm{mol}$ of $\mathrm{N}$-acetyl-D-glucosamine (GlcNac) from $1 \%(\mathrm{w} / \mathrm{v})$ colloidal chitin per hour under given conditions.

\section{RESUlTS AND DISCUSSION}

\section{A. Isolation and Screening for Chitinolytic Bacterium}

A total of 23 isolates were obtained from the soil samples based on their ability to degrade the colloidal chitin and with the purple zone on the plate (Fig. 1). By using this technique, it was easier to observe as compare to the conventional method without additional of dye [12]. Isolates SH 17 and SPBNO1 were selected for further study based on their chitinase production (data not shown).

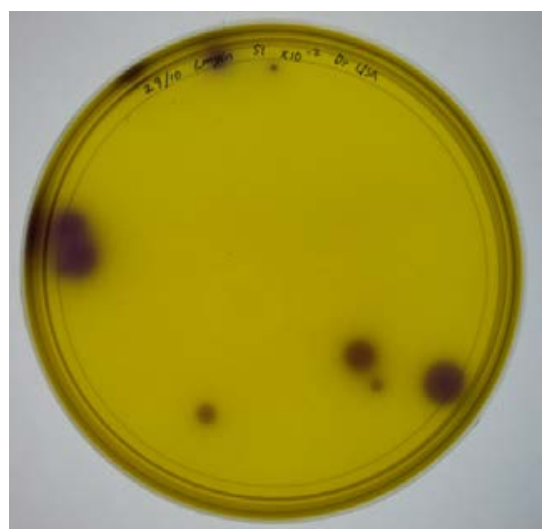

Fig. 1. Purple hydrolyzing zone produced by bacteria colony on the colloidal chitin agar supplemented with bromocresol purple.

\section{B. Identification of Potential Isolates Based on Their Biochemical Properties}

The identification of Isolates SH 17 and SPBNO 1 was carried out based on their morphological, biochemical and physiological characteristics according to the methods described in Bergey's Manual of Determinative Bacteriology [13]. The isolates were appeared in bacillus shape, gram negative, and non-spore forming (Table I). Based on all the results obtained with regards to the physiological and biochemical properties, Isolates SH 17 and SPBNO 1 were belonging to Enterobacter genus and Zymomonas genus, respectively. Further identification of the isolates till species level need to be carried out via molecular approached.

\begin{tabular}{|c|c|c|}
\hline Characteristic & SH 17 & SPBNO 1 \\
\hline Colony shape & Circular & Circular \\
\hline Elevation & Convex & Convex \\
\hline Margin & Entire edge & Entire edge \\
\hline Surface & Smooth & Smooth \\
\hline Color & Creamy white & Creamy \\
\hline Gram reaction & Negative & Negative \\
\hline Cellular morphology & Rod & Rod \\
\hline Endospore formation & Negative & Negative \\
\hline Oxidase & Negative & Negative \\
\hline Indole production & Negative & Negative \\
\hline Methyl red & Negative & Negative \\
\hline Voges-Poskauer reaction & Positive & Negative \\
\hline Citrate utilization & Positive & Negative \\
\hline Hydrogen sulfide production & Negative & Negative \\
\hline Lysine decarboxylase & Negative & Negative \\
\hline Arginine dihydrolase & Negative & Negative \\
\hline Motility & Negative & Negative \\
\hline Gelatin hydrolysis & Positive & Negative \\
\hline Starch hydrolysis & Negative & Negative \\
\hline Catalase production & Positive & Positive \\
\hline Oxidation-fermentation & Fermentative & Fermentative \\
\hline Triple ion sugar & $\begin{array}{c}\text { Slant agar: } \\
\text { positive, } \\
\text { Blunt agar: } \\
\text { negative }\end{array}$ & $\begin{array}{c}\text { Slant agar: } \\
\text { negative, } \\
\text { Blunt agar: } \\
\text { negative }\end{array}$ \\
\hline
\end{tabular}

\section{Optimization of Chitinase Production}

The optimization was carried out based on one-factor-at-a-time. Incubation time was first carried out to determine the optimum chitinase production for a period of 7 days. The results obtained in Fig. 2 showed the highest production was obtained after $24 \mathrm{~h}$ for both Enterobacter sp. $(6.70 \pm 0.15 \mathrm{U} / \mathrm{mL})$ and Zymomonas sp $(1.68 \pm 0.14 \mathrm{U} / \mathrm{mL})$. From Fig. 2, two chitinase production peaks can be observed for both bacteria. This might due to the production of toxic chemicals or inhibitors in the medium [9], [15]. Besides, different bacteria strain has different incubation time for high production of chitinase. After $24 \mathrm{~h}$ of fermentation, [5] found out that highest chitinase could be obtained by Aeromonas hydrophila. However Aeromonas punctata produced the highest chitinase production after 48 h [5]. For examples, [16] reported that after $48 \mathrm{~h}$ of incubation highest chitinase production was obtained from Bacillus cereus, B. alvei and B. sphaericus. The same pattern was observed by [17] with Microbispora sp. 


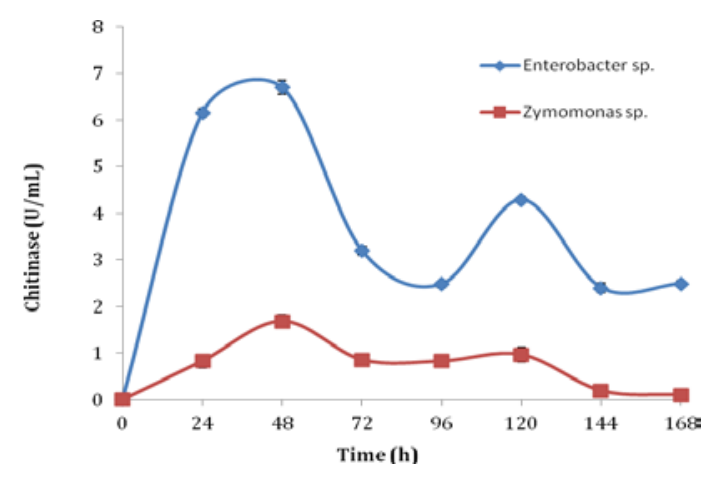

Fig. 2. Effect of incubation time on chitinase production.

Different concentrations of colloidal chitin ranging from 5 $\mathrm{g} / \mathrm{L}$ to $20 \mathrm{~g} / \mathrm{L}$ were investigated on the production. The incubation temperature, $\mathrm{pH}$ and agitation speed were maintained at $30^{\circ} \mathrm{C}, 7$ and $200 \mathrm{rpm}$, respectively. At 48 hours the chitinase produced by Enterobacter sp. and Zymomonas sp. were shown in Fig. 3. The optimum substrate concentration for both bacterial was different, where Enterobacter sp. gave highest chitinase production $(6.7 \pm$ $0.14 \mathrm{U} / \mathrm{mL}$ ) at lower concentration of colloidal chitin, which was $5 \mathrm{~g} / \mathrm{L}$. Whereas Zymomonas sp. produced highest chitinase $(2.78 \pm 0.21 \mathrm{U} / \mathrm{mL})$ at $15 \mathrm{~g} / \mathrm{L}$ of colloidal chitin. The results suggested substrate inhibition or end product inhibition which was $\mathrm{N}$-acetylglucosamine [18] occurred and influenced the production of chitinase by Enterobacter sp. This indicates that different strain of bacteria able to tolerate different concentration of colloidal chitin for the production of chitinase. These were proved by different researchers [3], [19], [20] i.e. [21] reported the maximum chitinase production was at $3 \mathrm{~g} / \mathrm{L}$ of colloidal chitin.

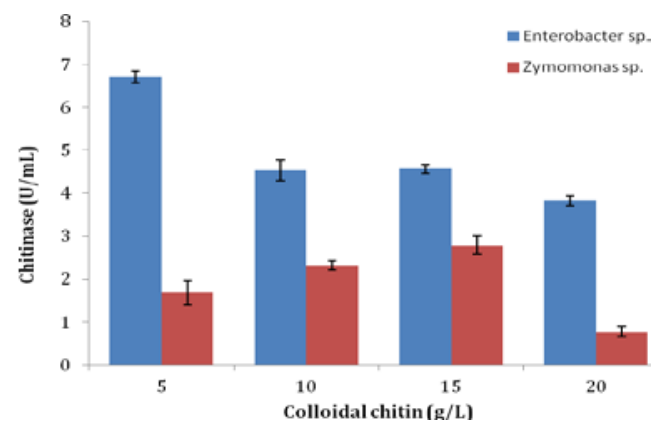

Fig. 3. Effect of colloidal chitin concentrations on chitinase production.

The effect of temperature on the production of chitinase by Enterobacter sp. and Zymomonas sp. were carried out based on the optimum colloidal chitin which was $5 \mathrm{~g} / \mathrm{L}$ and $15 \mathrm{~g} / \mathrm{L}$, respectively. To investigate the optimum incubation temperature for chitinase production, both bacteria were grown at $28-37^{\circ} \mathrm{C}$. This range of temperature was chosen is due to the isolates are mesophilic bacteria, which obtained from environmental. This is due to temperate plays an important role in various biological processes. Hence the growth of bacteria and enzyme production are affected with a slight change of the temperature. The optimum temperatures for both bacteria were at $30{ }^{\circ} \mathrm{C}$ (Fig. 4). Different microorganism has different optimum temperature for its growth and chitinase production [5], [22], [23].

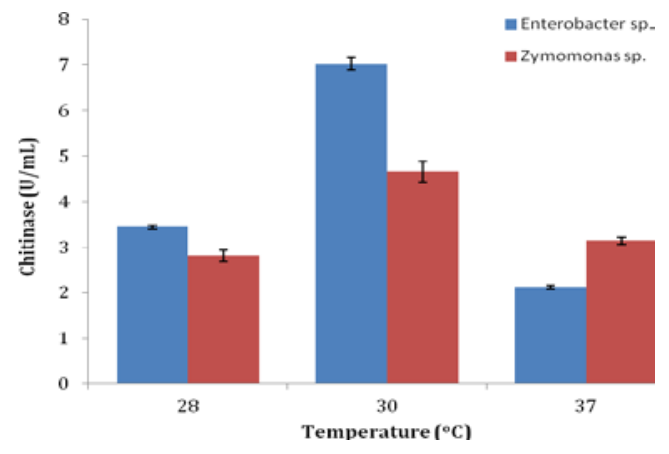

Fig. 4. Effect of temperature on chitinase production.

Based on Fig. 5, Enterobacter sp. growth well at neutral $\mathrm{pH}$ and has the highest chitinase production which was $5.58 \pm$ $0.15 \mathrm{U} / \mathrm{mL}$, while Zymomonas sp. growth well under slight acidic condition that was at $\mathrm{pH} 6$ with the chitinase production of $5.08 \pm 0.17 \mathrm{U} / \mathrm{mL}$. Some microorganisms are able to produce high amount of chitinase under alkaline condition [3], [5], [20], while some microorganism preferable acidic condition for chitinase production [22], [24]. This can conclude that $\mathrm{pH}$ plays an important role production of chitinase.

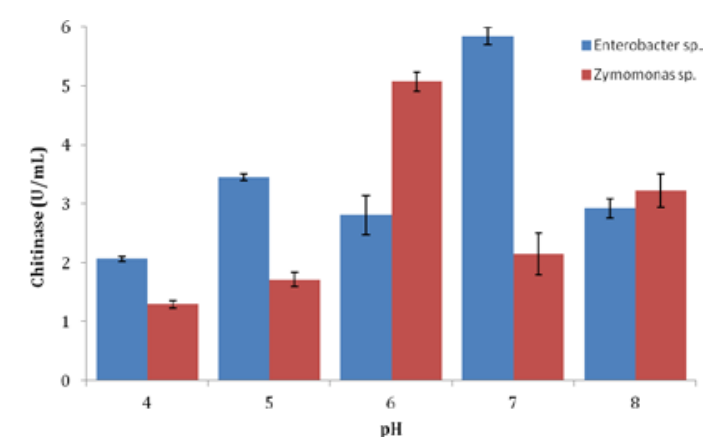

Fig. 5. Effect of $\mathrm{pH}$ on chitinase production.

\section{CONCLUSION}

Twenty three potential chitinase producing bacteria have been successfully isolated from environmental soil samples. Two potential isolates have tentatively identified as Enterobacter sp. and Zymomonas sp. and their production parameters have been optimized. Zymomonas sp. favorable acidic condition and produced acidic chitinase, while the chitinase obtained from Enterobacter sp. was at neutral $\mathrm{pH}$. Both isolates grown well at $30{ }^{\circ} \mathrm{C}$. Enterobacter sp. preferable low concentration of colloidal chitin, while Zymomonas sp. more desirable at higher concentration of colloidal chitin. To further identify these two isolates till the species level, 16S rDNA need to be carried out in future study.

\section{ACKNOWLEDGMENT}

The authors would like to thank Oniversiti Tunku Abdul Rahman, Department of Biological Science for the providing the facilities to carry out this project.

\section{REFERENCES}

[1] R. Islam and B. Datta. (March 2015). Diversity of chitinases and their industrial potential. Int. J. Appl. Res. [Online]. 1(4). pp 55-60. 
Available:

http://www.allresearchjournal.com/vol1issue4/PartB/pdf/1-4-18.1.pdf

[2] G. Vaaje-Kolstad, S. J. Horn, M. Sørlie, and V. G. H. Eijsink, "The chitinolytic machinery of Serratia marcescens - a model system for enzymatic degradation of recalcitrant polysaccharides," FEBS J., vol. 280, no. 13, pp. 3028-3049, July 2013.

[3] K. S. Rishad, S. Rebello, V. K. Nathan, S. Shabanamol, and M. S. Jisha, "Optimized production of chitinase from a novel mangrove isolate, Bacillus pumilus MCB-7 using response surface methodology," Biocatal. Agric. Biotechn., vol. 5, pp. 143-149, January 2016.

[4] W. Suginta, W. Chumjan, K. R. Mahendran, A. Schulte, and M. Winterhalter, "Chitoporin from Vibrio harveyi, a channel with exceptional sugar specificity,” J. Biol. Chem., vol. 288, no. 16, pp. 11038-11046, April 2013.

[5] M. K. Saima and I. Z. A. Roohi, "Isolation of novel chitinolytic bacteria and production optimization of extracellular chitinase," J. Genet. Eng. Biotechn., vol. 11, pp. 39-46, April 2013.

[6] M. Homthong, A. Kubera, M. Srihuttagum, and V. Hongtrakul. (October 2016). Isolation and characterization of chitinase from soil fungi, Paecilomyces sp., Agric. Nat. Resour. [Online]. Available: http://dx.doi.org/10.1016/j.anres.2015.09.005

[7] N. Rattanakit, A. Plikomol, S. Yano, M. Wakayama, and T. Tachiki, "Utilisation fo shrimp shellfish waste as a substrate for solid-state cultivation of Aspergillus sp. S1-13: Evaluation of a culture based on chitinase formation which is necessary for chitin-assimilation," $J$. Biosci. Bioeng., vol. 93, no. 6, pp. 550-556, June 2002.

[8] V. Gohel, V. Maisurai, and H. S. Chhatpar, "Utilization of various chitinous sources for production of mycolytic enzymes by Pantoea dispersa in bench-top fermenter," Enzyme Microb. Technol., vol. 40, no. 6, pp. 1608-1614, May 2007.

[9] M. A. Farag and S. T. Al-Nusarie, "Production, optimization, characterization and antifungal activity of chitinase produced by Aspergillus terrus,” Afr. J. Biotechn., vol. 13, no. 14, pp. 1567-1578, April 2014.

[10] P. Sudhakar and P. Nagarajan, "Production of chitinase by solid state fermentation from rice bran,” Int. J. Environ. Sci. Dev., vol. 1, no. 5, pp. 435-440, December 2010.

[11] N. K. S. Murthy and B. H. Bleakley. (2012). Simplified method of preparing colloidal chitin used for screening of chitinase-producing microorganisms. Internet J. Microbiol., [Online] 10(2). Available: http://dx.doi.org/10.5580/2bc3

[12] T. Agrawal and A. S. Kotasthane, "Chitinolytic assay of indigenous Trichoderma isolates collected from different geographical locations of Chhattisgarh in Central India,” Springer Plus, vol. 1, no. 73, pp. 1-3, December 2012.

[13] J. G. Holt, N. R. Krieg, P. H. A. Sneath, J. T. Staley, and S. T. Williams, Bergey's Manual of Determinative Bacteriology, 9th ed. Philadelphia, U.S.A: Lippincott Williams \& Wilkins, 2000.

[14] I. Saadoun, R. Al-Omari, Z. Jaradat, and Q Ababneh, "Influence of culture conditions of Streptomyces sp. (Strain $\mathrm{S}_{242}$ ) on chitinase production,” Pol. J. Microbiol., vol. 58, no. 4, pp. 339-345, August 2009.

[15] S. V. Nochur, M. F. Roberts, and A. L. Demain, "True cellulase production by Clostridium thermocellm grown on different carbon sources,” Biotechn. Lett., vol. 15, no. 6, pp. 641-646, June 1993.

[16] S. L. Wang and J. R. Hwang, "Microbial reclamation of shellfish wastes for the production of chitinases," Enzyme Microb. Technol., vol. 28, no. 4-5, pp. 376-382, March 2001.
[17] N. N. Nawani, B. P. Kapadnis, A. D. Das, A. S. Rao, and S. K. Mahajan, "Purification and characterization of a thermophilic and acidophilic chitinase from Microbispora sp. V2,” J. Appl. Microbiol., vol. 93, no. 6, pp. 965-975, November 2002.

[18] B. Bhushan, "Production and characterization of a thermostable chitinase from a new alkalophilic Bacillus sp. BG-11,” J. Appl. Microbiol., vol. 88, no. 5, pp. 800-808, May 2000.

[19] Y. S. Lee and K. Y. Kim, "Statistical optimization of medium components for chitinase production by Pseudomonas fluorescent strain HN 1205: role of chitinase on egg hatching inhibition of root-knot nematode," Biotechnol. Biotechnol. Equip., vol. 29, no. 3, pp. 470-478, February 2015.

[20] A. I. Melentiev, N. F. Galimzianova, E. A. Gilvanova, E. A. Shchelchkova, L. Y. Kuzmina, T. F. Boyko, N. G. Usanov, and G. E. Aktuganov, "Characterisation of novel alkaliphilic isolate of Bacillus mannailyticus, strain IB-OR17, displaying chitinolytic and antifungal activities," Adv. Microbiol., vol. 4, no. 8, pp. 455-464, June 2014.

[21] S. K. Karunya, D. Reetha, P. Saranraj, and D. J. Milton, "Optimization and purification of chitinase produced by Bacillus subtilis and its antifungi activity against plant pathogens,” Int. J. Pharm. Biol. Sci. Arch., vol. 2, no. 6, pp. 1680-1685, December 2011.

[22] P. Patidar, D. Agrawal, T. Banerjee, and S. Patil, "Optimization of process parameters for chitinase production by soil isolates of Penicillium chrysogenum under solid state fermentation," Process Biochem., vol. 40, no. 9, pp. 2962-2967, September 2005.

[23] K. M. Nampoothiri, T. V. Baiju, C. Sandhya, A. Sabu, G. Szakacs, and A. Pandey, "Process optimization for antifungal chitinase production by Trichoderma harzianum," Process Biochem., vol. 39, no. 11, pp. 1583-1590, July 2004.

[24] N. Aliabadi, S. Aminzadeh, A. A. Karkhane, and K. Haghbeen, "Thermostable chitinase from Cohnella sp. A01: Isolation and product optimization,” Braz. J. Microbiol., vol. 47, no. 4, pp. 931-940, October-December 2016.

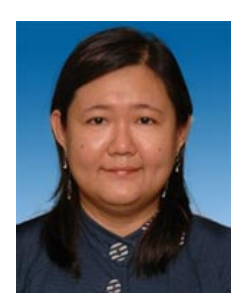

Lisa G. A. Ong received her BSc Hons (biotechnology), MSc in food biotechnology and Ph.D in industrial biotechnology from Universti Putra in Malaysia.

She joined the academic profession in 2005 Currently, she is working in Faculty of Science, Universiti Tunku Abdul Rahman as assistant professor. Since then, her research focuses on using fermentation technology to convert agricultural waste into value added products such as enzymes, animal feeds, biofuel and etc. She is involved in the enzymatic hydrolysis to improve the nutritional value in feeds. Besides that, she has obtained several grants related to her research focuses.

Dr Ong is a life-member for Malaysian Society for Microbiology (MSM), contributing members for American Society for Microbiology (ASM), a senior member for Asia Pacific Chemical, Biological \& Environmental Engineering Society (APCBEES), a member for Asian Federation of Biotechnology (AFOB) and Malaysian Society of Applied Biology (MSAB). She also contributes to the society as an abstract reviewer for conference papers, as a part of the conference organizing committee and reviewer for some journals. 